\title{
Development of a Hybrid Partial-Nitrification and Anammox Reactor with Stirrer
}

\author{
Liting Lyu', Yufang Zhu ${ }^{1}$, Kuo Zhang ${ }^{1}$, Yongguang Ma ${ }^{2 *}$, Yuan Pan ${ }^{1}$, Tong Zhu ${ }^{1}$ \\ ${ }^{1}$ Institute of Process Equipment and Environmental Engineering, School of Mechanical Engineering \\ and Automation, Northeastern University, Shenyang, P.R. China \\ ${ }^{2}$ Liaoning Provincial Machinery Research Institute Co., Ltd., Shenyang, P.R. China
}

Received: 31 January 2018

Accepted: 27 March 2018

\begin{abstract}
This study developed the hybrid partial-nitrification and anammox (HPNA) reactor to increase efficiency in ammonia nitrogen $\left(\mathrm{NH}_{4}^{+}-\mathrm{N}\right)$ removal. The HPNA reactor contained a fixed bed filled with biofilm carrier and a fluidized bed with mechanical stirrer to maximize withholding the sludge. The reactor achieved a total nitrogen (TN) removal efficiency of $70 \%$ and $\mathrm{NH}_{4}^{+}-\mathrm{N}$ removal efficiency of $84 \%$. The maximum nitrogen loading rate (NLR) of $6.1 \mathrm{~kg}-\mathrm{N} / \mathrm{m}^{3} / \mathrm{d}$ and nitrogen removal rate (NRR) of $4.7 \mathrm{~kg}-\mathrm{N} / \mathrm{m}^{3} / \mathrm{d}$ were achieved with a short hydraulic retention time (HRT) of $3 \mathrm{~h}$. After 160 days of operation, both the mixed liquid suspended solids (MLSS) and the mixed liquor volatile suspended solids (MLVSS) increased in the lower part (from 3.7 to $14.7 \mathrm{~g} / \mathrm{L}$ and 1.8 to $10.9 \mathrm{~g} / \mathrm{L}$, respectively) and the upper part (from 3.7 to $11.8 \mathrm{~g} / \mathrm{L}$ and 1.9 to $6.7 \mathrm{~g} / \mathrm{L}$, respectively). The proteins (PN)/ polysaccharides (PS) ratio increased from 0.96 to 1.1 in the lower part but decreased to 0.7 in the upper part. Bacterial community profiles generated from $16 \mathrm{~S}$ rRNA sequences further showed that the ammonium-oxidizing bacteria (AOB) Nitrosomonas and the anammox bacterium Brocadiales were enriched in the HPNA reactor.
\end{abstract}

Keywords: anammox, partial-nitrification, mechanical stirring, sludge characteristics, bacteria community

\section{Introduction}

Eutrophication, which has negative and irreversible effects on aquatic organisms [1], has been a worldwide problem for more than a century. It is mainly caused by the voluminous discharge of large animal farm wastewater, the use of nitrogen fertilizer, and the generation of landfill leachate, with ammonium nitrogen $\left(\mathrm{NH}_{4}{ }^{+} \mathrm{N}\right)$ being the main fraction generated. Thus, the

*e-mail: 34016854@qq.com efficient removal of $\mathrm{NH}_{4}^{+}-\mathrm{N}$ through a number of ways has been extensively studied.

The anaerobic ammonium oxidation (anammox) process combined with a partial-nitrification process to treat wastewater with a high concentration of $\mathrm{NH}_{4}^{+}-\mathrm{N}$ has gained interested in recent years. Conventionally, this combined process is carried out in a system with two different reactors, such as the SHARON-anammox process [2]. However, in recent years, several studies combining partial-nitrification with anammox in a single reactor have also been reported, such as the single nitrogen removal reactor using an anammox and partialnitrification (SNAP) system [3] and partial nitrification- 
anammox (PN/A) reactor [4]. The single-stage process generally has a higher volumetric nitrogen removal rate and lower capital costs than a system with two reactors, since no additional nitrification reactor is required for ammonium oxidation. The traditional up-flow anaerobic sludge blanket (UASB) reactors efficiently cultivate large granules with a diameter that could reach $0.7-1.5 \mathrm{~mm}$ $[5,6]$, but easily causes granular flotation $[7,8]$ leading to granule washout, which then eventually deteriorates the capacity of the reactor $[9,10]$. UASB reactors with fixed biofilms or flowing filler have the ability to catch the suspended sludge, yet they have difficulty achieving a high nitrogen removal rate (NRR) [3, 11, 12].

In response to these technical issues, an innovative hybrid reactor was previously designed that combined fluidized and fixed beds for anammox treatment [13]. Using this system, the nitrogen loading rate (NLR) of the reactor could be increased to $27.3 \mathrm{~kg}-\mathrm{N} / \mathrm{m}^{3} / \mathrm{d}$ with total nitrogen removal efficiency of $75 \%$. However, the same reactor also required both nitrite $\left(\mathrm{NO}_{2}^{-}-\mathrm{N}\right)$ and $\mathrm{NH}_{4}^{+}-\mathrm{N}$ as substrates.

In this study, the hybrid partial-nitrification and anammox (HPNA) reactor was developed that aimed to treat synthetic wastewater with a high concentration of ammonia nitrogen and maximize withholding the sludge. The fixed bed was designed to reduce the washout of the suspended sludge. The continuous stirring was designed to form shear stress and let the bubbles out of granules, which then eliminated flotation. It was hypothesized that $\mathrm{AOB}$ were active on the outer layers of the biofilm (or granule), producing a suitable amount of nitrite for the anammox organisms active in the inner layers.

\section{Material and Methods}

\section{Configuration of HPNA Reactor}

The lab-scale HPNA reactor with an effective volume of $7.5 \mathrm{~L}$ was made of acrylic resin and operated in a continuous-upflow mode (Fig. 1). Its internal diameter was $120 \mathrm{~mm}$ with a length/diameter ratio of 5.5 . The HPNA reactor had two major beds or zones. The first was the fluidized bed in the lower part (0-250 $\mathrm{mm}$ from the bottom) and the other was the fixed bed in the upper part $(250-600 \mathrm{~mm}$ from the bottom). In the upper part, a porous polyester pile fabric material (Ohyapile, Japan) was used as biomass carrier. The diameter and length of each pile fabric strip were $1 \mathrm{~mm}$ and $9 \mathrm{~mm}$, respectively. In the lower part, a mechanical stirrer (Z-2200, Tokyo Rikakikai, Japan) with six stainless steel blades was installed from the top of the reactor and the length of each blade was $30 \mathrm{~mm}$. Each lower and higher parts of the HPNA reactor were fixed with gas-liquid-solid separators (GSS). An aerator was positioned at the bottom of the reactor and dissolved oxygen (DO) was measured by a DO meter (OM-51, Horiba, Japan).

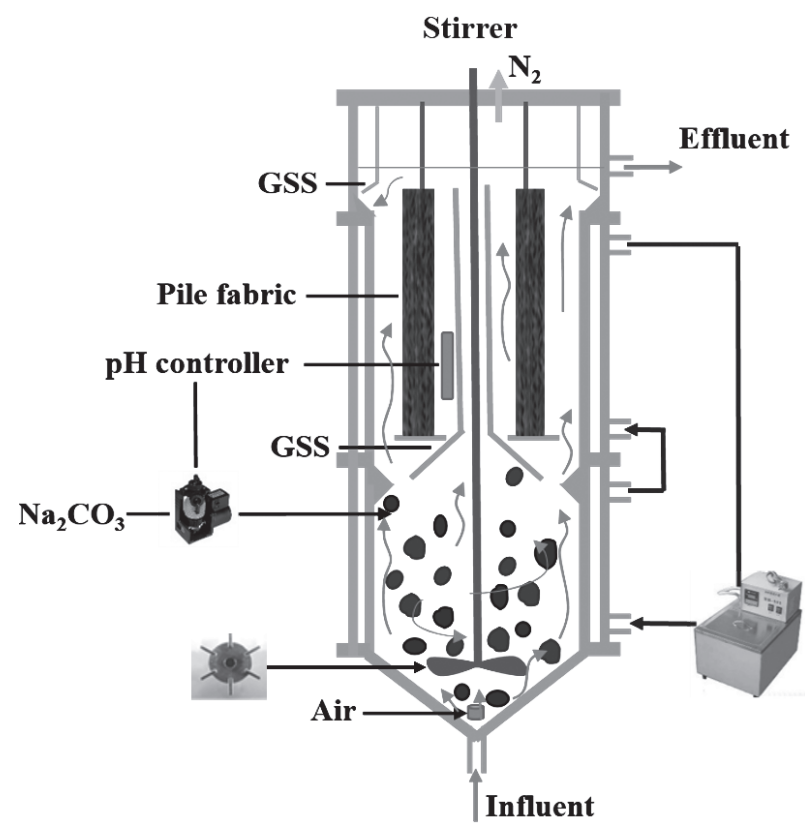

Fig. 1. Schematic of HPNA reactor. Seed sludge and feeding media.

The enriched anammox granular sludge (accounting for $75 \%$ of mixed liquid suspended solids (MLSS)) was collected from a $6.0 \mathrm{~L}$ hybrid reactor fed with synthetic wastewater [13, 14]. The reactor was seeded with $20 \mathrm{~g}$-MLSS of Anammox sludge to reach an initial concentration of $2.7 \mathrm{~g}-\mathrm{MLSS} / \mathrm{L}$. On the other hand, the nitrifying sludge was collected from a lab-scale filland-draw activated sludge reactor treated with ammonia nitrogen containing synthetic wastewater. This was added to the HPNA reactor with $3.75 \mathrm{~g}$-MLSS, producing an initial concentration of about $0.5 \mathrm{~g}-\mathrm{MLSS} / \mathrm{L}$.

The reactor was treated with ammonium sulfate as the only nitrogen source. The composition of synthetic wastewater contained 50-820 $\mathrm{mg} / \mathrm{L}^{2} \mathrm{NH}_{4}^{+}-\mathrm{N}, 1 \mathrm{~g} / \mathrm{L}$ $\mathrm{NaHCO}_{3}, 125-500 \mathrm{mg} / \mathrm{L} \mathrm{KHCO}_{3}, 54 \mathrm{mg} / \mathrm{L} \mathrm{KH}_{2} \mathrm{PO}_{4}$, $700 \mathrm{mg} / \mathrm{L} \mathrm{CaCl}_{2}, 700 \mathrm{mg} / \mathrm{L} \mathrm{KCl}, 500 \mathrm{mg} / \mathrm{L} \mathrm{MgSO}_{4}$, $500 \mathrm{mg} / \mathrm{L} \mathrm{NaCl}, 9 \mathrm{mg} / \mathrm{L} \mathrm{FeSO}_{4} \cdot 7 \mathrm{H}_{2} \mathrm{O}, 5 \mathrm{mg} / \mathrm{L}$ EDTA free acid, and $0.25 \mathrm{mg} / \mathrm{L} \mathrm{CuSO}_{4} \cdot 5 \mathrm{H}_{2} \mathrm{O}$ [15].

\section{HPNA Reactor Operation}

The HPNA reactor was operated at a constant temperature of $30 \pm 1^{\circ} \mathrm{C}$ by a water jacket and a $\mathrm{pH}$ level of 7.3-7.5 by adding $\mathrm{Na}_{2} \mathrm{CO}_{3}(100-150 \mathrm{~g} / \mathrm{L})$ through a pH-controller (NPH-6900, Nissin, Japan). The aeration rate was mediated according to the concentration of nitrogen components in effluent. The HPNA reactor was operated under continuous stirring of $100 \mathrm{rpm}$.

\section{Analytical Procedures}

Concentration of $\mathrm{NH}_{4}^{+}-\mathrm{N}$ was measured using orthophenyl phenol through a modified phonate method [16]. Concentrations of $\mathrm{NO}_{2}^{-}-\mathrm{N}$ and nitrate $\left(\mathrm{NO}_{3}^{-}-\mathrm{N}\right), 30-\mathrm{min}$ 
sludge volume indices $\left(\mathrm{SVI}_{30}\right)$, MLSS, and mixed liquor volatile suspended solids (MLVSS) were measured following the Standard Methods [17]. The granular sludge size was measured by a grainsize analyzer system (LA-920, Horiba, Japan). The morphology of sludge was observed by an electron microscope (Nikon Eclipse E600, Japan) with a digital camera (Nikon 4500, Japan). Extracellular polymeric substances (EPS) were extracted from sludge by formaldehyde plus $\mathrm{NaOH}$ [18], then the extracellular proteins (PN) and the polysaccharide (PS) content were determined according to the Lowry method [19].

\section{Bacterial Community Analysis}

The bacterial community structure was analyzed using the pyrosequencing approach. Sludge samples were taken from HPNA reactor at days 14 and 160. Universal primers 6F (5'-ACTCCTACGGGAGGCAGCAG-3') and 1492r(reverse primer: 5'-GGTTACCTTGTTACGACT-3') targeting the V4 region of 16S rRNA gene were used for polymerase chain reaction (PCR) amplification at Majorbio Bio-pharm Technology Corporation (Shanghai, China). Discussion on the community composition only focused on the abundant taxa, occurring at $>1 \%$ of the bacterial community $[20,21]$.

\section{Results and Discussion}

\section{Nitrogen Removal Performance}

In this study, the newly designed HPNA reactor was operated for 168 days. The performance of the reactor, sludge characteristics, and community structure were analyzed in detail.

\section{Rapid Startup of HPNA Reactor}

The HPNA reactor rapidly started up within 28 days (phase 1 in Fig. 2). During this period, the reactor was operated without aeration to improve the activity of the anammox community. The synthetic wastewater that had a total nitrogen (TN) concentration of about $100 \mathrm{mg} / \mathrm{L}\left(\mathrm{NO}_{2}^{-}-\mathrm{N}\right.$ to $\mathrm{NH}_{4}^{+}-\mathrm{N}$ ratio of 1.0$)$ was pumped into the reactor simultaneously for anammox reaction. The reactor was operated at a fixed hydraulic retention time (HRT) of $3.3 \mathrm{~h}$. On the $8^{\text {th }}$ day, TN removal efficiency and NRR reached $60 \%$ and $0.63 \mathrm{~kg}-\mathrm{N} / \mathrm{m}^{3} / \mathrm{d}$ (Fig. $2 \mathrm{~b}$ and c), respectively, indicating that anammox already had some activity. Previous studies also reported that the simultaneous nitritation-anammox reactor initiated with anammox produced a slightly higher and more stable NRR than initiating with partial nitrification [22].

From the $9^{\text {th }}$ day to the $28^{\text {th }}$ day, the HPNA reactor was operated under an intermittent aeration with a time interval of $15 \mathrm{~min}$ (bulk DO in this period was under $0.2 \mathrm{mg} / \mathrm{L}$ ). As shown in Fig. 2a, the influent $\mathrm{NH}_{4}^{+}-\mathrm{N}$ concentration increased from $80 \mathrm{mg} / \mathrm{L}$ to $110 \mathrm{mg} / \mathrm{L}$, with $\mathrm{NO}_{2}{ }^{-}-\mathrm{N}$ concentration gradually decreasing to zero, while HRT decreased from $7.2 \mathrm{~h}$ to $2.3 \mathrm{~h}$. On day 28, the removal rate of $\mathrm{NH}_{4}^{+}-\mathrm{N}$ reached $79 \%$ (Fig. 2b). NLR and NRR reached 1.2 and $0.7 \mathrm{~kg}-\mathrm{N} / \mathrm{m}^{3} / \mathrm{d}$, respectively (Fig. 2c). Chu et al. reported that when operated at influent ammonium concentration of $500 \mathrm{mg}-\mathrm{N} / \mathrm{L}$, a nitrogen volume loading rate of $0.25 \mathrm{~kg}-\mathrm{N} / \mathrm{m}^{3} / \mathrm{d}$ (HRT, 2d) was achieved in an SBR reactor after 60 days
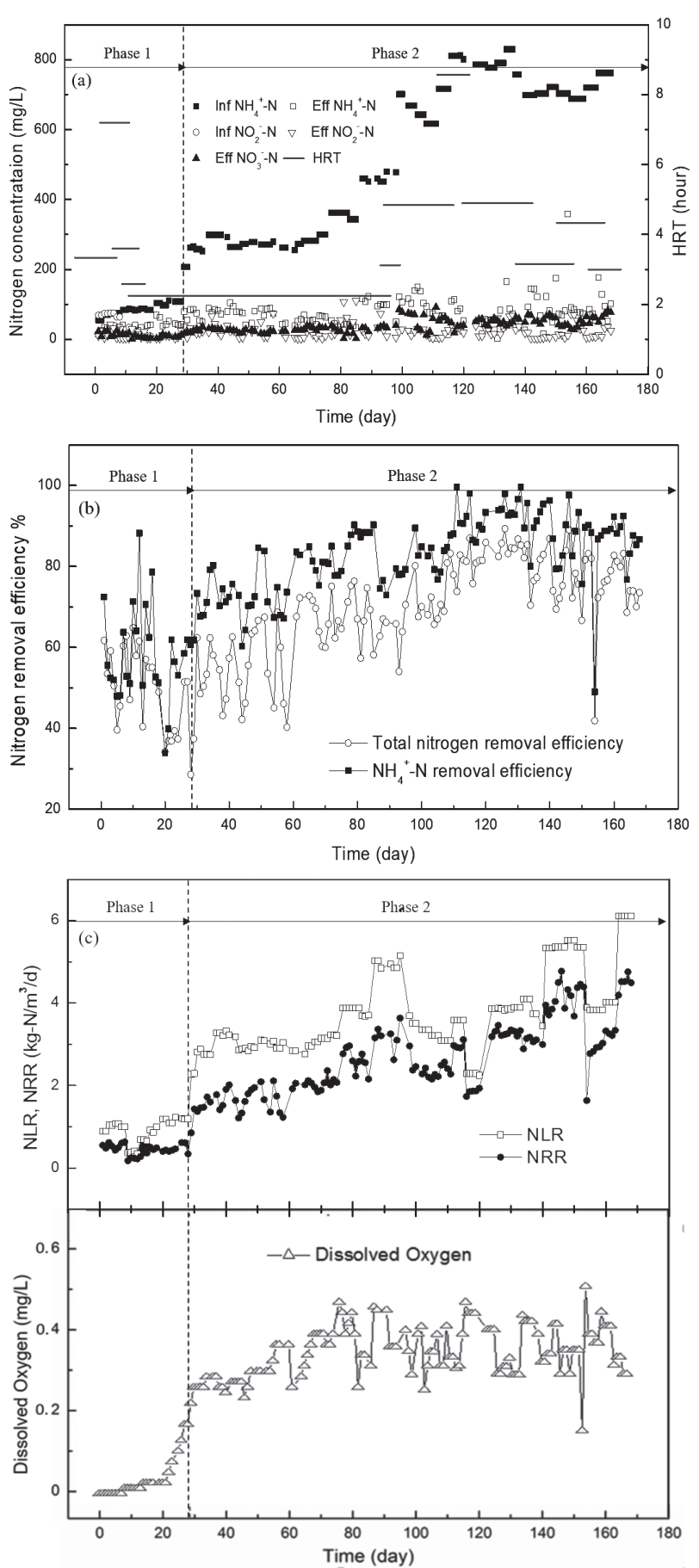

Fig. 2. HPNA reactor performance at different times. Variations of influent and effluent nitrogen. concentrations along with HRT a), nitrogen removal efficiency b), and value of NLR, NRR, and DO c). 
[23]. Kwak et al. also reported that a UASB reactor with biological filter could further achieve an NLR of $0.3 \mathrm{~kg}-\mathrm{N} / \mathrm{m}^{3} / \mathrm{d}$ along with HRT of $4 \mathrm{~h}$ after 46 days [24]. Compared with previous studies in these single-stage nitritaion-anammox reactors, this HPNA reactor had a relatively short startup period (28 days) with high adaptability to the rapid increase in NLR (0.4-1.2 $\left.\mathrm{kg}-\mathrm{N} / \mathrm{m}^{3} / \mathrm{d}\right)$ and short HRT (7.2-2.4 h).

\section{Stable operation and NLR Increasing Period}

From day 29 to 168 , the HPNA reactor was operated under continuous aeration. The feed medium was changed to contain only $\mathrm{NH}_{4}^{+}-\mathrm{N}$ to initiate simultaneous partial nitrification and anammox reaction (phase 2 in Fig. 2a). The concentration of $\mathrm{NH}_{4}^{+}-\mathrm{N}$ in influent increased from 250 to $830 \mathrm{mg} / \mathrm{L}$, while the $\mathrm{NH}_{4}^{+}-\mathrm{N}$ in effluent was always lower than $100 \mathrm{mg} / \mathrm{L}$. $\mathrm{NO}_{2}^{-}-\mathrm{N}$ in effluent was kept under $20 \mathrm{mg} / \mathrm{L}$, suggesting a proper control of aeration. The average $\mathrm{TN}$ and $\mathrm{NH}_{4}^{+}-\mathrm{N}$ removal efficiencies reached $70 \%$ and $84 \%$, respectively (Fig. 2b). A maximum NRR of $4.7 \mathrm{~kg}-\mathrm{N} / \mathrm{m}^{3} / \mathrm{d}$ was obtained with a maximum NLR of $6.1 \mathrm{~kg}-\mathrm{N} / \mathrm{m}^{3} / \mathrm{d}$ (Fig. 2c). HRT significantly varied (2.2 to $8.6 \mathrm{~h})$ to optimize nitrogen removal efficiency and NRR. The value of DO was also detected during the whole operation period. As influent ammonium concentration and NLR increase, DO should be improved gradually to maintain the stable $\mathrm{NH}_{4}^{+}-\mathrm{N}$ treatment. It has been reported that DO under $1 \mathrm{mg} / \mathrm{L}$ wouldn't inhibit anammox activity [22]. In this study, DO was kept at a relatively low value $(0.2-0.5 \mathrm{mg} / \mathrm{L})$ in order to reduce the anammox inhibition and ensure enough $\mathrm{NO}_{2}^{-}-\mathrm{N}$ concentration.

Table 1 compares the performances of HPNA reactor with other single-stage reactors in recent studies. Comparing with the above partial-nitrification and anammox reactors, the performance of the HPNA reactor was superior, which might have benefited from the short HRT and mechanical stirring. A shorter HRT represented higher NLR, and even a higher flow rate, which efficiently transported $\mathrm{NH}_{4}^{+}$and $\mathrm{NO}_{2}^{-}$to the top of the reactor, supplying substrate for the normal metabolisms of Anammox and ammonium-oxidizing bacteria (AOB) [26]. Meanwhile, mechanical stirring would form a fluid shear and thus enhance the mass transfer effect in the lower part [13]. Otherwise, the longtime stable operation and the relatively low concentration of effluent $\mathrm{NH}_{4}^{+}-\mathrm{N}$ indicated that the HPNA reactor was quite qualified for the high influent ammonium concentration.

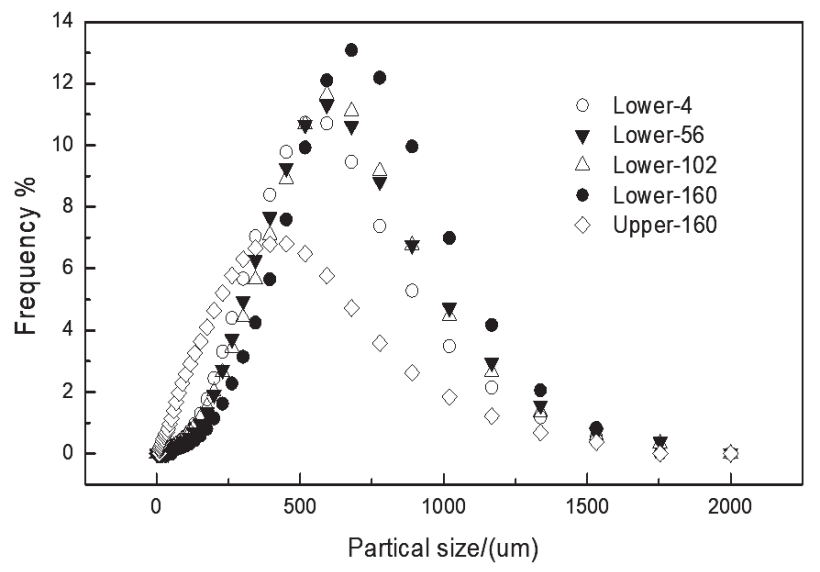

Fig. 3. Variations of SNA sludge size distribution during the experiment in the lower HPNA part on day 4 (Lower-4), day 56 (Lower-56), day 102 (Lower-102), and day 160 (Lower-160), and in the upper HPNA part on day 160 (Upper-160).

\section{Characteristics of Granular Sludge}

The granule diameter and distribution of SNA sludge in the lower and upper parts of the reactor were measured every 2 months during the whole operation period (Fig. 3). Table 2 summarizes the mean diameter and the corresponding distribution ratio. In the lower part of the reactor, the mean particle size of SNA sludge was maintained at 500-634 $\mu \mathrm{m}$ during the entire operation, which was higher than that in the upper part $(420 \mu \mathrm{m}$ on day 160$)$. This result indicated that continuous stirring produced shear stress that was able to sustain the granular diameter of the sludge, allowing for easier removal of bubbles outside the SNA granules.

Fig. 4 shows the surface morphology of SNA sludge under the microscope, which differed significantly between the lower and upper parts. Obviously, the typical red anammox sludge dominated in the lower part (left), while the brown-yellowish AOB sludge was more apparent in the upper part (right). These two types of sludge formed the desirable SNA granules. Similar sludge colors were also reported during a simultaneous partial nitrification-anammox process in other up-flow biofilm reactors $[22,27]$. These differences were mainly driven by the structure of HPNA reactor, where the lower fluid bed was optimum in generating anammox granules by stirring and the upper fixed biofilm helped withhold the easy-waste flocculent AOB.

Table 1. Final performance of different lab-scale single-stage reactors.

\begin{tabular}{|c|c|c|c|c|}
\hline Reactor system & $\begin{array}{c}\mathrm{NLR} \\
\left(\mathrm{kg}-\mathrm{N} / \mathrm{m}^{3} / \mathrm{d}\right)\end{array}$ & $\begin{array}{c}\mathrm{NRR} \\
\left(\mathrm{kg}-\mathrm{N} / \mathrm{m}^{3} / \mathrm{d}\right)\end{array}$ & $\begin{array}{c}\text { TN removals } \\
(\%)\end{array}$ & $\begin{array}{c}\text { HRT } \\
(\text { hour })\end{array}$ \\
\hline HPNA reactor & 6.1 & 4.7 & 70 & 3.3 \\
\hline Single-stage system [25] & 5.44 & 2.57 & 54.4 & 4 \\
\hline MBBR [4] & 3.6 & 3.16 & 82 & 1.34 \\
\hline Up-flow biofilm reactor [22] & 0.77 & 0.35 & 40 & 3 \\
\hline
\end{tabular}


Table 2. Summary of the mean diameter and the distribution ratio of particles.

\begin{tabular}{|c|c|c|c|c|c|}
\hline \multirow{2}{*}{} & \multicolumn{4}{|c|}{ Lower HPNA part } & Upper HPNA part \\
\cline { 2 - 6 } & Day 4 & Day 56 & Day 102 & Day 160 & Day 160 \\
\hline Mean diameter $(\mu \mathrm{m})$ & $498 \pm 15.27$ & $553 \pm 17.05$ & $557 \pm 17.55$ & $634 \pm 21.1$ & $420 \pm 8.98$ \\
\hline Distribution ratio & $52.14 \%$ & $49.75 \%$ & $50.45 \%$ & $42.89 \%$ & $75.22 \%$ \\
\hline
\end{tabular}

Note: data of mean diameters are presented as mean with SE, $\mathrm{n}=85$
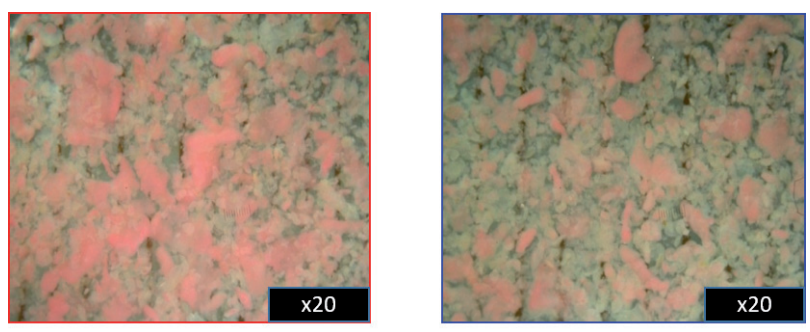

Fig. 4. Microscopic observation of SNA sludge on day 160 in the lower part (left) and in the upper part (right).

MLSS, MLVSS, $\mathrm{SVI}_{30}$, and EPS were measured only at the beginning (day 18) and the end of the whole period (day 160) (Table 3), since the stable operation of the reactor would be influenced by sampling. It was reported that sludge with $\mathrm{SVI}_{30}$ ranging from 50 to $100 \mathrm{~mL} / \mathrm{g}-\mathrm{MLVSS}$, indicated good settling property [28]. In this study, the $\mathrm{SVI}_{30}$ of SNA sludge was maintained at $63 \mathrm{~mL} / \mathrm{g}-\mathrm{MLVSS}$ in the upper part, and was reduced to $49 \mathrm{~mL} / \mathrm{g}$-MLVSS in the lower part. This further indicated better settling ability of both fixed bed and fluid bed. Generally, the floatation of Anammox granules could result in lower settling ability and washing out of the granular sludge $[8,9]$. Thus, the maintained settling property of the sludge in this study was attained by mechanical stirring, which in turn eliminated flotation [10]. Besides, both MLSS and MLVSS had remarkably increased after operating for
160 days. The MLVSS/MLSS ratio, which represents sludge activity, increased from $49 \%$ on 18 day to $74 \%$ and $57 \%$ on day 160 in the lower and upper parts, respectively. This was similar to the MLVSS/MLSS ratios reported in other studies, which range from $69-78 \%$ in an anammox process $[29,30]$. The higher SNA sludge concentrations in the lower part resulted from the maintained granules with good settling properties.

At the end of the operation after 160 days, both proteins and polysaccharides in the lower and upper parts increased from 58 to 108 and $84 \mathrm{mg} / \mathrm{g}$-MLVSS, and from 60 to 99 and $123 \mathrm{mg} / \mathrm{g}$-MLVSS, respectively (Table 3). High contents of extracellular polymer substrates (EPS), which mainly contained PN and PS, indicate dense structure of the granules [31], since EPS was primarily responsible for the structural and functional integrity of the aggregates and essential to their physicochemical and biological properties [32]. Moreover, larger amounts of PN in EPS could lead to better aggregation of anammox sludge [33]. Similarly, studies also found that the secretion of extracellular protein from anaerobic granules was stimulated under high hydrodynamic shear force [34]. In this study, the SNA granular sludge in the lower part accumulated much more $\mathrm{PN}$, which was probably due to the high hydrodynamic shear force generated by continuous stirring, suggesting a favorable aggregation.

The proteins-to-polysaccharides ratio (PN/PS) is usually used to evaluate granular stability, where a lower PN/PS ratio indicate higher strength and better

Table 3. Summary of the MLSS, MLVSS, sludge volumetric index (SVI30), and EPS contents in the lower and upper parts of the HPNA reactor on days 18 and 160 .

\begin{tabular}{|c|c|c|c|}
\hline & $\begin{array}{c}\text { Lower HPNA part } \\
\text { (on day 160) }\end{array}$ & $\begin{array}{c}\text { Upper HPNA part } \\
\text { (on day 160) }\end{array}$ & $\begin{array}{c}\text { Lower HPNA part } \\
\text { (on day 18) }\end{array}$ \\
\hline MLSS (g/L) & 14.7 & 11.8 & 3.7 \\
\hline MLVSS (g/L) & 10.9 & 6.7 & 49 \\
\hline MLVSS/MLSS (\%) & 74 & 57 & 60 \\
\hline SVI $_{30}$ (mL/g-MLVSS) & 49 & 63 & 58 \\
\hline EPS (mg/g-MLVSS) & 108 & 84 & 60 \\
\hline Proteins(PN) & 99 & 123 & 0.96 \\
\hline Polysaccharides(PS) & 1.1 & 0.7 & \\
\hline PN/PS & & & \\
\hline
\end{tabular}




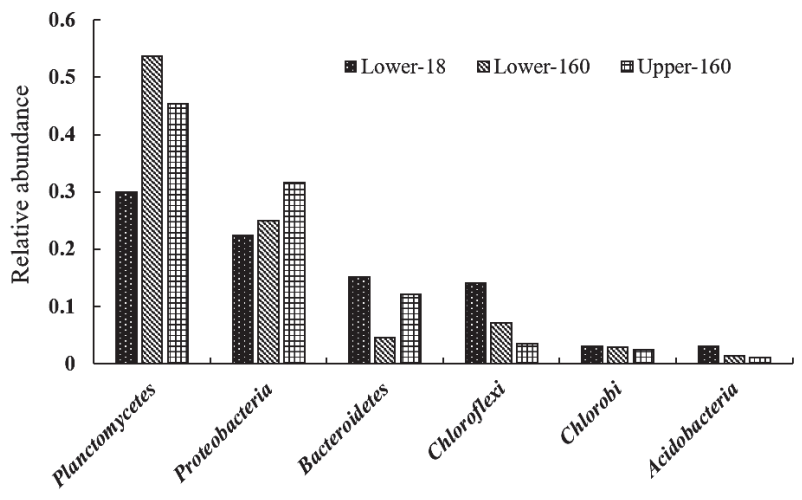

Fig. 5. Relative abundance of major phyla in three samples, which were harvested from the lower part on day 18 (Lower-18) and day 160 (Lower-160), and the upper part on day 160 (Upper-160); the abundance is presented as the percentage of the different phyla among the total reads in a sample (only prevalent populations taking $>1 \%$ of the community are shown).

settling ability [35]. Here, the HPNA reactor maintained relatively low levels of PN/PS ratio (0.7-1.1), indicating a strong structure of SNA granular and a favorable settling ability of HPNA reactor.

\section{Community Analysis}

\section{Analysis of Community Structure under Phylum Level}

Summary of the community relative abundances at the phylum level are shown in Fig. 5. The major phyla observed were Planctomycetes, accounting for $30-54 \%$ of the total reads, and Proteobacteria (22$32 \%)$, Bacteroidetes (5-15\%), and Chloroflexi (4-14\%). The 4 phyla accounted for more than $80 \%$ of the total reads in each sample. Other abundant phyla (2-6\%) included Chlorobi and Acidobacteria. The sample
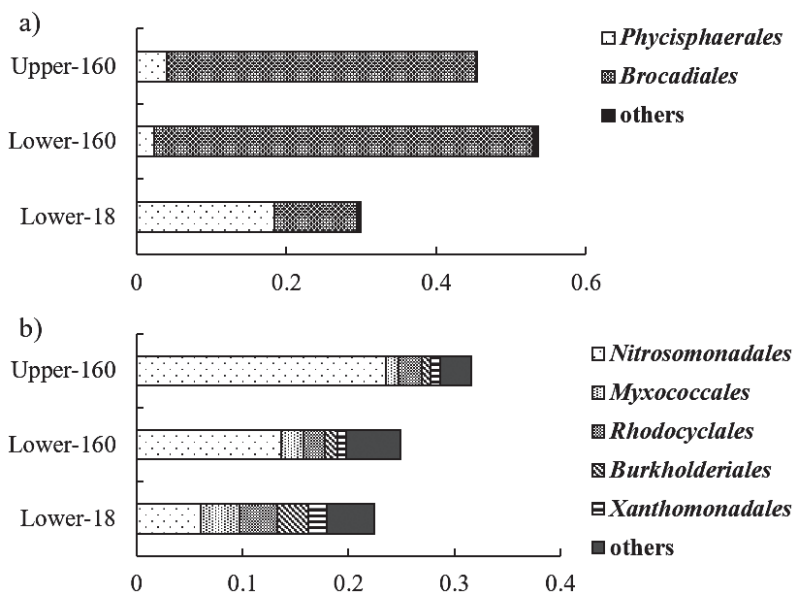

Fig. 6. Relative abundance of genera within the phyla; the genera under phylum Planctomycetes a) and the genera under phylum Proteobacteria b). taken from the lower part on day 18 was used as the control. After 160 days of operation, Planctomycetes, which included anammox species, dominated in both the lower and upper parts and increased to $54 \%$ and $45 \%$ of the community, respectively, compared to the control of $30 \%$. Proteobacteria also increased to $25 \%$ and $32 \%$ from $22 \%$ in the control, while Bacteroidetes decreased from $15 \%$ to $5 \%$ and $12 \%$, respectively. The phylum of Bacteroidetes possessed the ability to digest and grow on a variety of complex substrates such as cellulose, chitin, and agar [36]. Its decrease might be due to a lack of available organic matter. Chloroflexi was reported to utilize cellular compounds derived from dead biomass and metabolites from anammox bacteria [37]. This phylum was also detected in other single-stage nitritation-anammox reactors, and found to gradually increase toward the end of the reactor operations [23]. However, in this study, Chloroflexi decreased to $7 \%$ and $4 \%$ in the lower and the upper parts, respectively. This could indicate that the dominant bacteria in the HPNA reactor performed higher activities.

\section{Analysis of Community Structure under Genus Level}

The two most abundant phyla were further analyzed (Fig. 6). At the genus level, Brocadiales (Anammox bacteria) and Phycisphaerales accounted for more than $99 \%$ of the total Planctomycetes reads (Fig. 6a). Phycisphaerales was observed to account for $18 \%$ in the control, but decreased to $2 \%$ in the lower part and $5 \%$ in the upper part. This genus belonging to the class of Phycisphaerae was isolated from a marine alga in 2008 [38] and reported to account for $20 \%$ in a onestage nitritation-anammox reactor [23], but its function remains unknown. In this study, Phycisphaerales was replaced over time by the dominant Brocadiales, which largely increased from $11 \%$ in the control to $51 \%$ in the lower part and $41 \%$ in the upper part.

Fig. 6b) showed that Nitrosomonadales (AOB bacteria) was also the most dominant taxa in Proteobacteria, accounting for $6 \%, 14 \%$, and $24 \%$ in the control, the lower HPNA part, and the upper HPNA part, respectively. The relative abundances of Burkholderiales, Rhodocyclales, Myxococcales, and Xanthomonadales decreased after the operation period. Members of Burkholderiales and Rhodocyclales are heterotrophic denitrifying bacteria and could degrade and utilize organic compounds [39]. Xanthomonadales belonging to $\gamma$-Proteobacteria are capable of degrading aromatic compounds, and Myxococcales belonging to $\delta$-Proteobacteria play an important role in transforming organics [40]. The reduction of the four genera indicated that the SNA sludge had fine activity, thus the heterotrophic bacteria failed to use organics, which were released by dead bacteria, for metabolism.

The dominant anammox in the lower part and the dominant $\mathrm{AOB}$ in the upper part showed that 
the sectionalized HPNA reactor was suitable for generating and maintaining SNA sludge. The high abundance of anammox and AOB also benefited from the limitation in oxygen, which was reported in [27].

\section{Conclusions}

The HPNA reactor was quickly started up with 28 days and stably operated for 168 days at high influent ammonium concentration (700-800 $\mathrm{mg} / \mathrm{L})$, with a final NRR of $6.1 \mathrm{~kg}-\mathrm{N} / \mathrm{m}^{3} / \mathrm{d}$ and an ammonia nitrogen removal efficiency of $83 \%$. Meanwhile, a short HRT of $3.3 \mathrm{~h}$ was achieved. The SNA granule sludge in this reactor was well kept and had a favorable settling property due to continued stirring. Community analysis showed that Brocadiales was dominant in the lower part and Nitrosomonadales was prior in the upper part. HPNA reactor is efficient for sludge enrichment and co-culture of $\mathrm{AOB}$ and Anammox bacteria, which has guiding significance for practical engineering.

\section{Acknowledgements}

This work was supported by the National Natural Science Foundation of China (Nos. 51408105 and 21677030). The authors thank Prof. K. Furukawa and Prof. T. Fujii for their kindly suggestions and technical support.

\section{Conflict of Interest}

The authors declare no conflict of interest.

\section{References}

1. KARYDIS M., KITSIOU D. Eutrophication and environmental policy in the Mediterranean Sea: a review. Environmental Monitoring \& Assessment 184 (8), 4931, 2012.

2. SRI S.S., JOSEPH K. Nitrogen management in landfill leachate: application of SHARON, ANAMMOX and combined SHARON-ANAMMOX process. Waste Management 32 (12), 2385, 2012.

3. LIEU P.K., HATOZAKI R., HOMAN H., FURUKAWA $K$. Single-stage nitrogen removal using anammox and partial nitritation(snap)for treatment of synthetic landfill leachate. Japanese Journal of Water Treatment Biology 41 (2), 1627, 2006.

4. YANG J., TRELA J., ZUBROWSKA-SUDOL M., PLAZA E. Intermittent aeration in one-stage partial nitritation/ anammox process. Ecological Engineering 75, 413, 2015.

5. MORALES N., RÍO Á.V.D., VÁZQUEZ-PADÍN J.R., MÉNDEZ R., CAMPOS J.L., MOSQUERA-CORRAL A. The granular biomass properties and the acclimation period affect the partial nitritation/anammox process stability at a low temperature and ammonium concentration. Process Biochemistry 51 (12), 2134, 2016.

6. ROGHAIR M., STRIK D.P.B.T.B., STEINBUSCH K.J.J., WEUSTHUIS R.A., BRUINS M.E., BUISMAN C.J.N. Granular sludge formation and characterization in a chain elongation process. Process Biochemistry 51 (10), 1594, 2016.

7. DAPENA-MORA A., CAMPOS J.L., MOSQUERACORRAL A., JETTEN M.S., MÉNDEZ R. Stability of the anammox process in a gas-lift reactor and a SBR. Journal of Biotechnology 110 (2), 159, 2004.

8. CAMPOS J.L., RÍO A.V.D., PEDROUSO A., RAUX P., GIUSTINIANOVICHC E.A. Granular biomass floatation: a simple kinetic/stoichiometric explanation. Chemical Engineering Journal 311, 63, 2017.

9. CHEN J.W., JI Q.X., ZHENG P., CHEN T.T., WANG C.H., MAHMOOD Q. Floatation and control of granular sludge in a high-rate anammox reactor. Water Research 44 (11), 3321, 2010.

10. CHEN H., MA C., YANG G.F., WANG H.Z., YU Z.M., JIN R.C. Floatation of flocculent and granular sludge in a high-loaded anammox reactor. Bioresource Technology 169 (5), 409, 2014.

11. BAGCHI S., BISWAS R., NANDY T., BAGCHI S. Alkalinity and dissolved oxygen as controlling parameters for ammonia removal through partial nitritation and anammox in a single-stage bioreactor. Journal of Industrial Microbiology \& Biotechnology 37 (8), 871, 2010.

12. SONG Y.X., LIAO Q., YU C., XIAO R., TANG C.J., CHAI L.Y., DUAN C.S. Physicochemical and microbial properties of settled and floating anammox granules in upflow reactor. Biochemical Engineering Journal 123, 75, 2017.

13. HEINRICH D., MUELLER-ECKHARDT C., STIER W. Nitrogen removal performance of a hybrid anammox reactor. Bioresource Technology 102 (12), 6650, 2011.

14. FURUKAWA K., ROUSE J.D., IMAJO U., NAKAMURA, K., ISHIDA H. Anaerobic oxidation of ammonium confirmed in continuous flow treatment using a non-woven biomass carrier. Japanese Journal of Water Treatment Biology 38 (38), 87, 2002.

15. CHEN T., ZHENG P., SHEN L., DING S., MAHMOOD Q. Kinetic characteristics and microbial community of anammox-EGSB reactor. Journal of Hazardous Materials 190 (1-3), 28, 2011.

16. KANDA J. Determination of ammonium in seawater based on the indophenol reaction with o-phenylphenol (opp). Water Research 29 (12), 2746, 1995.

17. CLESCERI L.S., GREENBERG A.E., EATON A.D. Standard methods for the examination of water and wastewater. American Journal of Public Health \& the Nations Health 56 (3), 387, 1998.

18. LIU H., FANG H.H. Extraction of extracellular polymeric substances (EPS) of sludges. Journal of Biotechnology 95 (3), 249, 2002.

19. LOWRY O.H., ROSEBROUGH N.J., FARR A.L., RANDALL R.J. Protein measurement with the folin phenol reagent. Journal of Biological Chemistry 193 (1), 265, 1951.

20. HYOKWAN B., KYUNGSOON P., YUNCHUL C., JINYOUNG J. Distribution of anammox bacteria in domestic wwtps and their enrichments evaluated by realtime quantitative pcr. Process Biochemistry 45 (3), 323, 2010.

21. WANG Q., GARRITY G.M., TIEDJE J.M., COLE J.R. Naïve bayesian classifier for rapid assignment of rRNA 
sequences into the new bacterial taxonomy. Applied \& Environmental Microbiology 73 (16), 5261, 2007.

22. CHO S., FUJII N., LEE T., OKABE S. Development of a simultaneous partial nitrification and anaerobic ammonia oxidation process in a single reactor. Bioresource Technology 102 (2), 652, 2011.

23. CHU Z.R., WANG K., LI X.K., ZHU M.T., YANG L., ZHANG J. Microbial characterization of aggregates within a one-stage nitritation-anammox system using high-throughput amplicon sequencing. Chemical Engineering Journal 262, 41, 2015.

24. KWAK W., MCCARTY P.L., BAE J., HUANG Y.T., LEE, P.H. Efficient single-stage autotrophic nitrogen removal with dilute wastewater through oxygen supply control. Bioresource Technology 123 (123), 400, 2012.

25. ABBAS G., ZHENG P., WANG L., LI W., SHAHZAD K., ZHANG H., HASHMI M.Z., ZHANG J., ZHANG M. Ammonia nitrogen removal by single-stage process: A review. Journal- Chemical Society of Pakistan, 36 (4), 775, 2014.

26. ALI M., CHAI L.Y., MIN X.B., TANG C.J., AFRIN S., LIAO Q., WANG H.Y., PENG C., SONG Y.X., ZHENG P. Performance and characteristics of a nitritation airlift reactor under long-term hrt shortening. International Biodeterioration \& Biodegradation 111, 45, 2016.

27. LI X., SUNG S. Development of the combined nitritationanammox process in an upflow anaerobic sludge blanket (UASB) reactor with anammox granules. Chemical Engineering Journal 281, 837, 2015.

28. ARRIAGADA C., GUZMÁN-FIERRO V., GIUSTINIANOVICH E., ALEJO-ALVAREZ L., BEHAR, J., PEREIRA L., CAMPOS V., FERNÁNDEZ K., ROECKEL M. NOB suppression and adaptation strategies in the partial nitrification-anammox process for a poultry manure anaerobic digester. Process Biochemistry 58, 258, 2017.

29. YANG J., ZHANG L., FUKUZAKI Y., HIRA D., FURUKAWA K. High-rate nitrogen removal by the anammox process with a sufficient inorganic carbon source. Bioresource Technology 101 (24), 9471, 2010.

30. LI B., ZHANG W., YAN X., HUANG X., LI J., LI Y. Startup and performance stability of a nitritationanammox reactor using granular sludge. Polish Journal of Environmental Studies 26 (1), 173, 2017.

31. QIAN F., WANG J., SHEN Y., WANG Y., WANG S., CHEN X. Achieving high performance completely autotrophic nitrogen removal in a continuous granular sludge reactor. Biochemical Engineering Journal 118, 97, 2017.

32. BAZAKA K., CRAWFORD R.J., NAZARENKO E.L., IVANOVA E.P. Bacterial Extracellular Polysaccharides. Bacterial Adhesion. Springer Netherlands 213, 2011.

33. DING Z., BOURVEN I., GUIBAUD G., HULLEBUSCH E.D.V., PANICO A., PIROZZI F., ESPOSITO G. Role of extracellular polymeric substances (EPS) production in bioaggregation: Application to wastewater treatment. Applied Microbiology \& Biotechnology 99 (23), 9883, 2015.

34. WU J., ZHOU H.M., LI H.Z., ZHANG P.C., JIANG J. Impacts of hydrodynamic shear force on nucleation of flocculent sludge in anaerobic reactor. Water Research $\mathbf{4 3}$ (12), 3029, 2009.

35. REN L.F., NI S.Q., LIU C., LIANG S., ZHANG B., KONG Q. Effect of zero-valent iron on the start-up performance of anaerobic ammonium oxidation (anammox) process. Environmental Science \& Pollution Research International 22 (4), 2925, 2015.

36. GUPTA R.S., LORENZINI E. Phylogeny and molecular signatures (conserved proteins and indels) that are specific for the bacteroidetes and chlorobi species. BMC Evolutionary Biology 7 (1), 71, 2007.

37. KINDAICHI T., YURI S., OZAKI N., OHASHI A. Ecophysiological role and function of uncultured Chloroflexi in an anammox reactor. Water Science \& Technology A Journal of the International Association on Water Pollution Research 66 (12), 2556, 2012.

38. FUKUNAGA Y., KURAHASHI M., SAKIYAMA, Y., OHUCHI M., YOKOTA A., HARAYAMA S. Phycisphaera mikurensis gen. nov., sp. nov., isolated from a marine alga, and proposal of Phycisphaeraceae fam. nov., Phycisphaerales ord. nov. and Phycisphaerae classis nov. In the phylum Planctomycetes. Journal of General \& Applied Microbiology 55 (4), 267, 2009.

39. SILVA C.C., HAYDEN H., SAWBRIDGE T., MELE P., DE PAULA S.O., SILVA L.C., VIDIGAL P.M., VICENTINI R., SOUSA M.P., TORRES A.P. Identification of genes and pathways related to phenol degradation in metagenomic libraries from petroleum refinery wastewater. Plos One 8 (4), e61811, 2013.

40. LUEDERS T., KINDLER R., MILTNER A., FRIEDRICH, M.W., KAESTNER M. Identification of bacterial micropredators distinctively active in a soil microbial food web. Applied \& Environmental Microbiology 72 (8), 5342, 2006. 